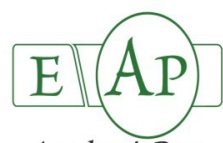

AcademicPres

\title{
Quantifying Some Physiological and Productivity Indices of Canola (Brassica napus L.) Crop under an Arid Environment
}

\author{
Sibgha NOREEN ${ }^{1}$, Shakeela NOOR ${ }^{1}$, Shakeel AHMAD ${ }^{2}$, Fehmeeda BIBI ${ }^{3}$, \\ Mirza HASANUZZAMAN**
}

\author{
IBahauddinZakariyaUniversity,InstituteofPureandAppliedBiology, Multam Pakistan; sibgha.noreen@bzu.edupk;shakeelanoor803@yahoo.com \\ 2Bahauddin Zakariya University, Faculty of Agricultural Sciencesand Technology,Departmentof Agronomy, Multam, Pakistan;shakeelahmad@bzu.edupk \\ ${ }^{3}$ Bahauddin Zakariya University, Faculty ofVeterinarySciences, Multam, Pakistan;fehmida01@gmail.com \\ ${ }^{4}$ Sher-e-Bangla Agriculture University, Faculty of Agriculture, Department of Agronomy, Dhake, \\ Bangladesh;mhzsauagz@yahoo.com (*orrespondingauthor)
}

\begin{abstract}
Canola (Brassica napus L.) crop ranks third after soybean and palm among oilseed crops for production of vegetable oil and meal for human and livestock, respectively around the globe. The cultivars of canola crop vary greatly in their yield potential in response to eco-edaphic factors under different production environments. Therefore, research studies were undertaken to evaluate eight cultivars of canola crop 'Shiralee', 'Dunkled', 'Bulbul-98', 'Ac-Excel', 'Cyclone', 'Rainbow', 'DGL' and 'Faisal Canola' for quantifying some physiological and productivity indices under normal growing conditions. The results showed that various cultivars of canola differed significantly amongst themselves with respect to biological yield, chlorophyll content, protein content, nutrient composition and components of seed yield. Among the cultivars, cvs. 'Bulbal-98' and 'Rainbow' produced maximum biological yield and seed yield, respectively, Furthermore, maximum yield harvested from cv. 'Rainbow' was associated with higher total seed weight plant ${ }^{-1}$, while cv. 'Faisal Canola' maintained higher chlorophyll content than other ones. Cultivar 'Dunkled' contained higher $\mathrm{K}^{+}$nutrient by $21.13 \mathrm{mg} \mathrm{g}^{-1}$ in leaf tissues compared to minimum $\left(9.73 \mathrm{mg} \mathrm{g}^{-1}\right)$ in 'DGL' cultivar. The higher amount of $\mathrm{Na}^{+}$content $\left(12.16 \mathrm{mg} \mathrm{g}^{-1}\right)$ was determined in cv. 'AC Excel'. Cultivar 'Rainbow' maintained higher photosystem (II) activity and had greater partitioning ability of photo-assimilates in the seed tissues. Of various chlorophyll fluorescence parameters, quantum yield of photosystem II and electron transport performance index could be used as a selection criterion for breeding of canola cultivars.
\end{abstract}

Keywords: seed yield, shoot length, potassium nutrient, sodium nutrients, chlorophyll content, proteins content, chlorophyll fluorescence

\section{Introduction}

Canola (Brassica napus L.) belonging to the botanical family of Brassicaceae is one of the most promising oilseed crop (McCaffery et al., 2009). Its production ranks at third position after soybean and palm and contributes to about 15 percent of the total vegetable oil in the world (Banga et al., 2007). In Pakistan, it is most important winter oilseed crop, which shares about $10 \%$ towards vegetable oil production (Economic Survey of Pakistan, 2015). It is also grown extensively for production of forage, because of containing low fiber and high protein content (Wiedenhoeft and Bharton, 1994) and seed cake meal for livestock (Bañuelos et al., 2002). The oil is of premium quality in terms of containing low levels of erucic acid (less than 2\%) in oil and glucosinolates (less than $30 \mu \mathrm{mol} \mathrm{g}^{-1}$ ) in meal for consumption of human and livestock, respectively. The oil contains 62 per cent oleic acid (monounsaturated fatty acids), 20 per cent linoleic acid and $9 \%$ linolenic acid (polyunsaturated fatty acids). The meal contains $30-40 \%$ protein, and is also being substituted for soybean meal (Muhammad et al., 2007). The presence of higher amount of erucic acid and glucosinolates in the indigenous rapeseed crop is not favored by human and livestock for consumption purpose (Mailer, 2009). Presently, Pakistan is facing deficiency of oil by two-thirds of its total requirement (Government of Pakistan, 2014). The production lacks far behind of requirement due to lower productivity of oilseed crops and further its cultivation on marginal lands (Sahrawatet al.,2011).

The gap between demand and supply is being met mainly through import of palm oil. The country imported a quantity of 2.32 million tons at the cost of PKR 207.66 billion (US \$ 2.07 billion) during the year 2012-2013 (Government of Pakistan, 2014). The heavy burden on the country's exchequer could be lessened by growing high yielding cultivars and mass cultivation over a large area. The planting area under canola crop stretched from 
10,700 ha to 14,700 ha, and its production increased from 9,200 tons to 17,000 tons during the period from the year 2005-2006 and 2012-2013 (Government of Pakistan, 2014). The lower production is mainly attributed to planting on marginal areas, low yielding canola cultivars and more importantly its cultivation in under drought-prone areas and also on saline soils (Stricker et al., 1997). Canola is highly susceptible to drought stress and its yield is reduced to a substantial level during the period from flowering to seed setting stage (Din et al., 2011).

Among the currently grown oilseed crops, canola has potential to bridge the gap between demand and supply, because of its wider adaptability under various production environments (McCaffery $e t$ al., 2009; Aminpanah, 2013). The selection of canola crop cultivars is determined primarily by their yield potential capacity and enhanced yield forming processes (Daun, 2006). The components of seed yield are highly variable and influenced greatly by one's genetic background, environmental conditions agronomic practices and resultantly their interactions amongst themselves (Sidlauskas and Berinotas, 2003; Goodwin, 2004). Furthermore, Diepenbrock (2000) reported that biological yield of oilseed rape crops are significantly influenced by their relative crop growth rate and duration of vegetative growth period under the growing conditions. The proportionate quantity of seed yield varies from 28 to $50 \%$ of the total biomass, while the remaining 50 to $70 \%$ accounts for vegetative biomass (Rathke et al., 2006). Kumar et al, (1994) found that photosynthetic capacity, transpiration rate and biological yield are the determinants for seed yield production. The close relationships were found between seed yield and number of pods plant $^{-1}$, number of seeds pod ${ }^{-1}$ and 1000 -seed weight in various canola cultivars (Cantagallo et al., 1997). However, yield potential of canola crop is more of a site-specific characteristic in response to prevailing environmental conditions (Rathke et al., 2006). The negative correlations were observed between protein and seed oil content, i.e, amount of protein content increased with concurrent reduction in oil content in various cultivars of canola crop (Fayyaz-ul- Hassan, 2007; Aminpanah, 2013). The varieties of canola exhibited a great variation in biological yield, seed yield and quality of oil with respect to protein and glucosinolate contents. These were closely related to progressive vegetative growth during the early part of season, higher plant density and reduced shattering of pods at maturity (Snowdon and Friedt, 2004; Rathke et al., 2006). The rapeseed varieties also varied greatly due to one's genetic makeup, integrated nutrients management and differentiation in partitioning of assimilates between reproductive and vegetative plant organs (Zhao and Wang, 2004; Rathke et al., 2006).Various investigators (Kolte et al., 2000; Khoshanazar et al., 2000; Stringam et al., 2000; and Din et al., 2011) studied quantitative traits in various cultivars of canola crop. They found significant variability for various traits related to seed yield and yield determinants, i.e. number of pods plant ${ }^{-1}$, number of branches plant $^{-1}$ and grain yield plant $t^{-1}$. El-Habbasha and Mostafa (2009) reported non-significant differences between varieties, except for plant height and seed yield. On the other hand, Khehra and Singh (1998) and Paramjit et al. (1991) reported significant variability for various seed yield of canola crop. Din et al. (2011) reported that productivity of canola is cumulative effects of number of branches plant ${ }^{-1}, 100$ - seed weight and number of pod plant ${ }^{-1}$ in various varieties of canola crop.

Canola crop being a recent introduction in Pakistan, thereby it requires continuing research for screening of advanced genotype/ cultivars, which are highly productive and adaptative under growing environment. This necessitates that the yield potential could be exploited according to agronomic requirements of various cultivars (Tahir et al., 2007). The reason being that productivity of canola varieties is greatly influenced by various eco-edaphic factors, genetic make-up, and quality of planting seed, fertilizer management practices and particularly financial and management resources available to the farmers. Therefore, a research study was carried out to delineate the differences among various cultivars of canola crop with respect to biological yield, biochemical parameters, nutrient assimilation and components of seed yield grown under normal growing conditions.

\section{Materials and Methods}

\section{Experimental location}

The research study was conducted at the research station of Institute of Pure and Applied Biology, Bahauddin Zakariya University, Multan, Pakistan during the winter crop season 20132014. The experiment consisted of eight cultivars, 'Faisal Canola', 'DGL', 'Bulbul-98', 'Shiralee', 'Dunkled', 'Ac-Excel', 'Cyclone' and 'Rainbow' which were planted to quantify their comparative performance under normal growing environments. In Pakistan, Oilseeds Research Institute (ORI), Ayub Agricultural Research Institute, Faisalabad is an institution for research and delivery of oilseed cultivars. Data regarding cultivars used in the study are: 'Faisal Canola' (cross: 'KS-75' × 'Rainbow', origin: ORI, Pakistan); 'DGL' (Dark Green Leaf, origin: ORI, Pakistan); 'Bulbul-98' (introduction, origin: Australia); 'Shiralee' (introduction, origin: Australia); 'Dunkled' (introduction, origin: Australia); 'Ac-Excel' (germplasm, origin: Saskatoon); 'Cyclone' (germplasm, origin, Australia); 'Rainbow' (germplasm, origin: Australia)] The representative soil sample was analyzed for physical and chemical characteristics according to methods of Ryan et al. (2001). The soil of growth medium contained soil pHs 8.2; ECe $1.7 \mathrm{~d} \mathrm{Sm}^{-1} ; 0.80$ percent organic matter, $4.89 \mathrm{mg} \mathrm{g}^{-1} \mathrm{~N} ; 6.80 \mathrm{mg} \mathrm{g}^{-1} \mathrm{P} ; 83.6 \mathrm{mg} \mathrm{g}^{-1} \mathrm{~K}$ and 5.89 percent calcium carbonate content. The textural class of the soil was silty clay loam, having alkaline in reaction and calcareous in nature.

\section{Experimental layout}

The treatments involving eight cultivars were arranged in a completely randomized design and each treatment was replicated four times. Ten healthy seed of different canola cultivars, free from any mechanical / diseased infestation were dibbled in each experimental pot during first week of November, 2013. After germination, thinning was done at three leaf stage and four seedlings of uniform in size and development were maintained during the growth period. The moisture content was maintained at field capacity to avoid water stress condition. The pots were kept in a naturally illuminated wire - house to avoid damage from birds and mammals. The plants were sprayed with insecticides to control sucking insect pests during the season.

\section{Collection of data}

The quantum of fresh biological yield produced by various cultivars was evaluated by harvesting of plants. The plants were divided into shoots and roots organs. The plant material was dried in an oven at $70^{\circ} \mathrm{C}$ till constant weight for estimation of dry biological yield. The chlorophyll content was measured by using portable Chlorophyll Meter (Minolta SPAD-502, Japan). The recent fully expanded $3^{\text {rd }}$ leaf from apex at day 50 after sowing, which coincided pod forming stage was selected to collect data on chlorophyll content. The shoot length was measured on a meter scale. The plant 
274

material was processed for chemical analysis of potassium and sodium concentration in leaf tissues according to methods of (Ryan et al., 2001). The amounts of total soluble proteins and total amino acids were determined in seeds according to methods of Bradford (1997) and Hamilton and Van Slyke (1943) respectively. Data for seed yield components, number of branches plant ${ }^{-1}$, number of pods plant $^{-1}$ and total weight plant ${ }^{-1}$ were recorded at maturity. Chlorophyll fluorescence measurements were made by employing Flour Pen (FP-100), fixed with an array of six emitting diodes. The diodes were fixed on the leaf (first adapted for 30 minutes) to ensure that all photosystem II reaction centre were in an open state and faceted in the clip on a spot of $4 \mathrm{~mm}$ diameter to provide homogeneous elucidation.

\section{Statistical analysis}

Data were analysed statistically using analysis of variance (SPSS Verr. 10). The F-value was calculated at the probability level $(p<0.05)$. The significant data were identified by calculating least significant difference (Steel et al., 1997).

\section{Results}

The statistical analysis of data revealed that cultivars of canola differed significantly $(\mathrm{p}<0.05)$ in terms of fresh and dry weights of shoot organ (Table 1). Maximum shoot fresh weight of $27.78 \mathrm{~g}$ plant ${ }^{-1}$ was produced by cv. 'bulbul-98', while minimal quantity of 16.67 g plant $^{-1}$ was gathered from cv. 'Faisal Canola'. The values of shoot fresh weight ranged from 16.67 to $27.78 \mathrm{~g} \mathrm{plant}^{-1}$ in various cultivars. Maximum quantity of shoot dry weight $\left(1.57 \mathrm{~g} \mathrm{plant}^{-1}\right)$ and minimal value of $\left(0.68 \mathrm{~g} \mathrm{plant}^{-1}\right)$ was collected from $\mathrm{cv}$. 'Bulbul-98' and cv. 'Shiralee' respectively. The various cultivars also showed non-significant $(p<0.05)$ differences with regard to production of fresh and dry weight of root organ. Maximum quantity of root fresh weight $2.19 \mathrm{~g} \mathrm{plant}^{-1}$ was obtained from $\mathrm{cv}$.
'Faisal Canola' and minimum production of $1.55 \mathrm{~g}$ plant $^{-1}$ was harvested from cv. 'DGL' at maturity. On the other hand, maximum root dry weight of $0.39 \mathrm{~g}$ plant ${ }^{-1}$ was gathered from $\mathrm{cv}$. 'Faisal Canola' and minimum quantity of $0.29 \mathrm{~g} \mathrm{plant}^{-1}$ by cv. 'Dunkled' among various cultivars. Comparatively, various cultivars differed a little in production of fresh and dry weight of root organ. The cultivar 'Bulbul-98' produced maximum quantity of shoot fresh and dry weights. Contrary to it, maximum quantity of root fresh and dry weights was gathered from cv. 'Faisal Canola' (Table 1).

The statistical analysis of data indicated that various cultivars differed statistically non-significant in maintenance of total free amino acids in the seed portion. Maximum content of total free amino acids by $9.04 \mathrm{mg} \mathrm{g}^{-1}$ was found in seed of cv. 'Faisal Canola' while its minimal value of $6.07 \mathrm{mg} \mathrm{g}^{-1}$ was determined in $\mathrm{cv}$. 'Cyclone'. The cultivars 'Dunkled', 'DGL' and 'Ac-Excel' were statistically at par with each other. Contrarily, the cultivars differed significantly $(\mathrm{p}<0.01)$ in maintaining total soluble proteins among themselves. Maximum quantity of total soluble proteins by 8.62 $\mathrm{mg} \mathrm{g}^{-1}$ was obtained in seed tissues of $\mathrm{cv}$. 'Rainbow' while its minimal amount by $1.07 \mathrm{mg} \mathrm{g}^{-1}$ was found in seed of cv. 'Faisal Canola'. The maximum quantity of total free amino acid and total soluble proteins were determined in cr. 'Faisal Canola' and cv. 'Rainbow', respectively (Table 1).

The cultivars differed significantly $(\mathrm{p}<0.05)$ in shoot length. Comparing the cultivars, cv. 'DGL' was the tallest followed by 'AcExcel' then 'Shiralee' and 'Dunkled' with values of 95.73, 93.25, 88.38 , and $88.00 \mathrm{~cm}$, respectively (Table 2). The statistical analysis of data showed that cultivars differed significantly $(\mathrm{p}<0.05)$ in maintenance of chlorophyll content in their leaf tissues at day 50 after planting which coincided with pod formation stage. Among various cultivars, maximum $S P A D$ value of 43.25 were recorded in cv. 'Faisal canola' while its minimal value of 38.17 was determined in cv. 'Dunkled'. The cultivars 'Shiralee', 'Cyclone' and 'DGL' were

Table 1. Biological yield and protein content in cultivars of canola

\begin{tabular}{|c|c|c|c|c|c|c|}
\hline Cultivars & $\begin{array}{l}\text { Shoot fresh wt. } \\
\left.\text { (g plant }^{-1}\right)\end{array}$ & $\begin{array}{l}\text { Shoot dry wt. } \\
\left(\text { g plant }^{-1}\right)\end{array}$ & $\begin{array}{l}\text { Root fresh wt. } \\
\left(\text { g plant }^{-1}\right)\end{array}$ & $\begin{array}{l}\text { Root dry wt. } \\
\left(\text { g plant }^{-1}\right)\end{array}$ & $\begin{array}{c}\text { Total free Amino } \\
\text { acids }(\mathrm{mg} / \mathrm{g})\end{array}$ & $\begin{array}{c}\text { Total soluble } \\
\text { Proteins }(\mathrm{mg} / \mathrm{g})\end{array}$ \\
\hline Shiralee & $26.09 \mathrm{bc}$ & $0.68 \mathrm{a}$ & $2.02 \mathrm{bc}$ & $0.33 \mathrm{a}$ & $7.43 \mathrm{e}$ & $4.37 \mathrm{~b}$ \\
\hline Dunkled & $22.82 \mathrm{bc}$ & $1.35 \mathrm{~b}$ & $1.86 \mathrm{ab}$ & $0.29 a$ & $6.48 b$ & $6.14 c$ \\
\hline Bulbul-98 & $27.78 \mathrm{bc}$ & $1.57 \mathrm{bc}$ & $1.84 \mathrm{a}$ & $0.31 \mathrm{a}$ & $6.34 b$ & $3.12 b$ \\
\hline Ac-Excel & $19.14 a$ & $0.75 \mathrm{a}$ & $1.88 \mathrm{ab}$ & $0.34 \mathrm{a}$ & $6.90 \mathrm{c}$ & $4.23 b$ \\
\hline Cyclone & $20.49 a$ & $1.35 b$ & $1.79 \mathrm{a}$ & $0.30 \mathrm{a}$ & $6.07 \mathrm{a}$ & $5.90 c$ \\
\hline Rainbow & $23.32 \mathrm{bc}$ & $1.38 \mathrm{bc}$ & $1.89 \mathrm{ab}$ & $0.36 \mathrm{a}$ & $7.09 \mathrm{~d}$ & $8.62 \mathrm{~d}$ \\
\hline DGL & $20.17 \mathrm{a}$ & $1.06 \mathrm{~b}$ & $1.55 \mathrm{a}$ & $0.35 \mathrm{a}$ & $7.69 f$ & $5.59 c$ \\
\hline Faisal Canola & $16.67 \mathrm{a}$ & $1.23 \mathrm{~b}$ & $2.19 \mathrm{c}$ & $0.39 b$ & $9.04 \mathrm{~g}$ & $1.07 \mathrm{a}$ \\
\hline LSD & 4.62 & 0.30 & 0.29 & 0.08 & 0.19 & 1.15 \\
\hline
\end{tabular}

ns $=$ Non significant; ${ }^{* *},{ }^{* * *}=$ Significant at $\leq 0.01$ and 0.001 , respectively.

Table 2. Chlorophyll content and component of seed yield of canola (Brassica napus L.)

\begin{tabular}{|c|c|c|c|c|c|c|}
\hline Cultivars & $\begin{array}{l}\text { SPAD } \\
\text { values }\end{array}$ & $\begin{array}{c}\text { No. of branches / } \\
\text { plant }\end{array}$ & $\begin{array}{c}\text { No. of pods/ } \\
\text { plant }\end{array}$ & $\begin{array}{c}\text { 100-seeds wt. } \\
\left(\text { g plant }^{-1}\right)\end{array}$ & $\begin{array}{c}\text { Total seed wt. } \\
\text { g plant }^{-1}\end{array}$ & $\begin{array}{l}\text { Plant height } \\
(\mathrm{cm})\end{array}$ \\
\hline Shirale & $42.12 b c$ & $2.75 \mathrm{a}$ & $118 \mathrm{~b}$ & $0.39 a$ & $3.46 \mathrm{~b}$ & $88.38 \mathrm{~b}$ \\
\hline Dunkled & $38.17 \mathrm{a}$ & $4.00 \mathrm{a}$ & $153 \mathrm{~d}$ & $0.48 \mathrm{a}$ & $0.26 a$ & $88.00 \mathrm{~b}$ \\
\hline Bulbul-98 & $40.95 \mathrm{abc}$ & $4.75 b$ & $136 c$ & $0.41 \mathrm{a}$ & $6.18 b$ & $85.83 \mathrm{~b}$ \\
\hline Ac-Excel & $39.82 \mathrm{ab}$ & $3.25 \mathrm{a}$ & $129 \mathrm{c}$ & $0.39 \mathrm{a}$ & $8.22 \mathrm{bc}$ & $93.25 b$ \\
\hline Cyclone & $42.70 \mathrm{bc}$ & $3.50 \mathrm{a}$ & $199 \mathrm{e}$ & $0.49 a$ & $7.88 \mathrm{bc}$ & $75.65 b$ \\
\hline Rainbow & $39.17 \mathrm{a}$ & $3.75 \mathrm{a}$ & $131 \mathrm{c}$ & $0.55 b$ & $9.26 \mathrm{bc}$ & $77.80 \mathrm{~b}$ \\
\hline DGL & $42.87 \mathrm{c}$ & $4.00 \mathrm{a}$ & $141 c$ & $0.52 b$ & $7.60 \mathrm{bcd}$ & $95.73 \mathrm{~b}$ \\
\hline Faisal Canola & $43.25 \mathrm{c}$ & $3.00 \mathrm{a}$ & $108 \mathrm{a}$ & $0.37 \mathrm{a}$ & $5.06 b$ & $68.40 \mathrm{a}$ \\
\hline LSD & 2.89 & 1.41 & 4.99 & 0.15 & 2.33 & 13.40 \\
\hline
\end{tabular}

ns = Non significant $;{ }^{*},{ }^{* *}=$ Significant at $\leq 0.05$ and 0.01 , respectively. 
Table 3. Components of nutrients in cultivar of canola (Brassica napus L.)

\begin{tabular}{|c|c|c|c|c|}
\hline Cultivars & $\begin{array}{c}\text { Leaf } \mathrm{K}^{+} \\
\left(\mathrm{mg} \mathrm{g}^{-1}\right) \text { dry wt. }\end{array}$ & $\begin{array}{c}\text { Root } \mathrm{K}^{+} \\
\left(\mathrm{mg} \mathrm{g}^{-1}\right) \text { dry wt. }\end{array}$ & $\begin{array}{c}\text { Leaf } \mathrm{Na}^{+} \\
\left(\mathrm{mg} \mathrm{g}^{-1}\right) \text { dry wt. }\end{array}$ & $\begin{array}{c}\text { Root } \mathrm{Na}^{+} \\
\left(\mathrm{mg} \mathrm{g}^{-1}\right) \text { dry wt. }\end{array}$ \\
\hline Shiralee & $11.92 \mathrm{a}$ & $16.23 a$ & $4.38 \mathrm{~b}$ & $4.71 \mathrm{a}$ \\
\hline Dunkled & $21.13 \mathrm{bcd}$ & $24.46 b$ & $6.84 \mathrm{~d}$ & $4.87 \mathrm{a}$ \\
\hline Bulbul-98 & $18.84 \mathrm{bc}$ & $26.17 b$ & $3.88 \mathrm{a}$ & $5.75 a$ \\
\hline Ac-Excel & $19.39 \mathrm{bc}$ & $25.57 b$ & $3.68 \mathrm{a}$ & $12.16 \mathrm{~b}$ \\
\hline Cyclone & $19.98 \mathrm{bc}$ & $26.02 b$ & $6.52 b c$ & $5.65 b$ \\
\hline Rainbow & $19.67 \mathrm{bc}$ & $24.97 b$ & $3.99 b c$ & $4.89 \mathrm{a}$ \\
\hline DGL & $9.73 \mathrm{a}$ & $26.97 b$ & $5.19 b c$ & $4.57 \mathrm{a}$ \\
\hline Faisal Canola & $17.80 \mathrm{bc}$ & $24.65 b$ & $2.18 \mathrm{a}$ & $5.55 b$ \\
\hline LSD & 2.42 & 3.94 & 1.13 & 1.01 \\
\hline
\end{tabular}

found similar in maintaining chlorophyll content in their leaf tissues at pod formation stage (Table 2).

The seed yield plant ${ }^{-1}$ of canola crop is a cumulative effect of various yield components, i.e. number of branches plant $t^{-1}$, number of pods plant ${ }^{-1}, 100$-seed weight and total seed weight plant ${ }^{-1}$. The statistical analysis revealed that various cultivars differed significantly $(\mathrm{p}<0.05)$ in the production of number of branches plant ${ }^{-1}$. The maximum number of branches plant ${ }^{-1}$ by $(4.75)$ were produced by cv. 'Bulbul-98', while minimum number of branches plant ${ }^{-1}$ of (2.75) were recorded in cv. 'Shiralee'. Cultivars 'Dunkled' and 'DGL' produced similar number of branches plant $t^{-1}$. There were statistically significant $(p<0.05)$ differences in production of pods plant ${ }^{-1}$ by various cultivars. The maximum (199) and minimum (108) number of pods plant ${ }^{-1}$ were produced by $\mathrm{cv}$. 'Cyclone' and cv. 'Faisal Canola' respectively. Cultivars 'Bulbul-98', 'Rainbow' and 'Ac- Excel' were found similar in production of number of pods plant ${ }^{-1}$.

The statistically analysis of data indicated that cultivars differed significantly $(p<0.05)$ with respect to 100 -seed weight. The cultivars 'Rainbow' and 'DGL' had the highest 100 -seed weight and having a little difference between them. While, cv. 'Faisal Canola' had the lowest seed weight $(0.37 \mathrm{~g})$ and the highest found in cv. 'Rainbow'. Cultivars 'Shiralee' and 'Ac-Excel' were similar with each other in production of 100 seed weight. The values of 100 seed weight ranged from 0.37 to $0.55 \mathrm{~g}$ in various cultivars. Cultivars also differed significantly $(\mathrm{p}<0.01)$ in production of total seed weight plant $t^{-1}$. Cultivar 'Rainbow' had the highest seed weight plant $^{-1}$ (9.26 g), while 'Cyclone' and 'DGL' cultivars differed nonsignificantly in total seed weight plant ${ }^{-1}$. The value of total seed weight plant ${ }^{-1}$ in various cultivars ranged from 0.26 to $9.26 \mathrm{~g}$ (Table 2).

The statistical analysis of data revealed that nutrient concentrations of $\mathrm{K}^{+}$and $\mathrm{Na}^{+}$ions differed in various cultivars (Table 3). There were statistically significant $(\mathrm{p}<0.001)$ differences in maintenance of $\mathrm{K}^{+}$concentration in leaf tissue of various cultivars. Maximum concentration of $\mathrm{K}^{+}$nutrient $\left(21.13 \mathrm{mg} \mathrm{g}^{-1}\right)$ was determined in cv. 'Dunkled', while the minimal quantity of $9.73 \mathrm{mg} \mathrm{g}^{-1}$ was maintained by cultivar 'DGL'. Cultivar 'Ac- Excel' and 'Cyclone' maintained similar quantity of $\mathrm{K}^{+}$content in their leaf tissues. Furthermore, cultivars also differed significantly $(\mathrm{p}<0.01)$ in maintenance of differential concentration of $\mathrm{K}^{+}$ nutrients, in their root organ. The maximum quantity of $26.97 \mathrm{mg}$ $\mathrm{K}^{+} \mathrm{g}^{-1}$ was absorbed by cv. 'DGL' while an amount of of $16.23 \mathrm{mg}$ $\mathrm{g}^{-1}$ was determined in cv. 'Shiralee'. Cultivars 'Bulbul-98' and 'Cyclone' maintained similar quantity of $\mathrm{K}^{+}$nutrient in their root tissue. Data for $\mathrm{Na}^{+}$concentration in leaf tissues of various varieties differed significantly $(\mathrm{p}<0.001)$. Cultivar 'Dunkled' absorbed maximum quantity of $6.84 \mathrm{mg} \mathrm{Na}^{+} \mathrm{g}^{-1}$ compared to $\mathrm{cv}$. 'Faisal
Canola' having $2.18 \mathrm{mg} \mathrm{Na}^{+} \mathrm{g}^{-1}$ in the root tissue. Cultivar 'Bulbul98 ' and 'Rainbow' had similar quantities of $\mathrm{Na}^{+}$content in their root tissues. The statistical analysis of data further showed that cultivars differed significantly $(\mathrm{p}<0.01)$ in maintenance of differential concentration of $\mathrm{Na}^{+}$nutrients in their root tissues. The highest quantity of $12.16 \mathrm{mg} \mathrm{Na}^{+} \mathrm{g}^{-1}$ absorbed by root tissues of 'Ac-Excel' whereas the lowest amount of $4.57 \mathrm{mg} \mathrm{Na}^{+} \mathrm{g}^{-1}$ was determined in 'DGL' cultivar. Cultivars 'Shiralee', 'Dunkeld' and 'Rainbow' maintained 4.71, 4.87 and $4.89 \mathrm{mg} \mathrm{Na}^{+} \mathrm{g}^{-1}$ respectively. Whereas, cvs. 'Bulbul-98', 'DGL' and 'Faisal canola' were also statistically non- significant amongst each other.

Inter varietal-changes in the biophysical parameters derived from the transients curves JIP-test are presented at radar plot (Fig. 1). RC/AOS (density of reaction center) was increased in cv. 'Bulbul-98', while it decreased in cv. 'Ac-Excel' and cv. 'Rainbow'. Data indicated further that maximum photosynthesis was recorded in cv. 'Bulbul-98' and minimum in cvs. 'Ac-Excel' and 'Rainbow'. According to value of performance index, cultivar 'Faisal Canola' showed maximum values, but density of reaction center was greater in cv. 'Bulbul-98'.

\section{Discussion}

Various cultivars of canola crop differed to a greater extent in the production of biological yield under the prevailing environments. Maximum and minimum fresh and dry biological yield of shoot organ was harvested from cv. 'Bulbul-98' and cv. 'Shiralee' respectively. On the other hand, maximum and minimum fresh and dry biological yield were harvested from cv. 'Faisal Canola' and cv.'DGL' respectively. The differences in the production of biological yield among eight cultivars are due to differential growth habit, rate of photosynthetic activity and more predominantly by their genetic background. Mukhtar et al. (2013) also reported that various varieties of canola crop produced different quantities of biological yield with regard to the shoot and root organ. Several other researches (Wiedenhoeft and Bharton, 1994; Yasari and Patwardhan, 2008; Das, 1998) also found significant difference in the production of biological yield, which were closely correlated with photosynthetic capacity and translocation of photosynthates among different plant parts (Khan et al., 2006a). These results agree with those of Cheema et al. (2010) and Ali et al. (2011) who found close relationships between total dry matter accumulation and maintenance of phosphosynthatic efficiency by various varieties of canola crop. The canola varieties differed greatly in production of biological yield, because of inherent genetic variability and importantly outcome of geneticx environment interaction (Khan et al., 2006b). 


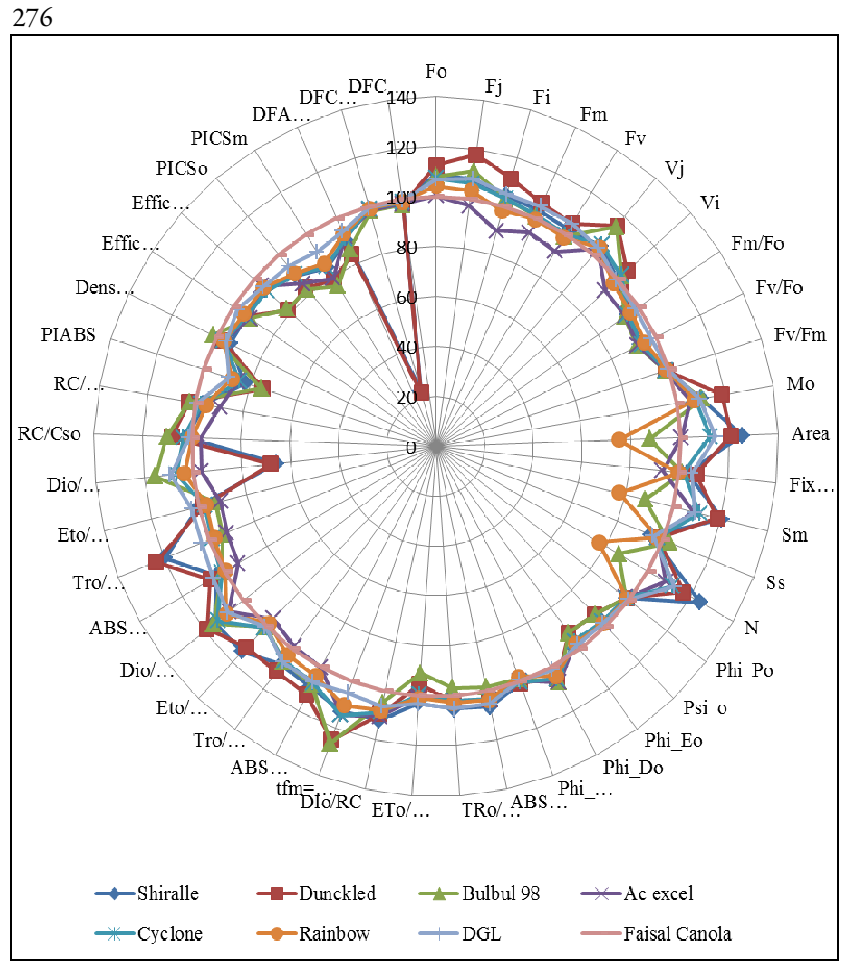

Fig. 1. Radar plot showing the changes in chlorophyll $a$ florescence transients parameters in dark adapted cultivars of canola (Brassica napus L.)

The cultivars differed appreciably in maintenance of protein contents. Maximum and minimum protein content was recorded in cvs. 'Rainbow' and 'Faisal Canola', respectively. The significant differences in protein contents in cultivars of canola have also been reported by various investigators (Ahmed et al., 2008; Parveen et al., 1996; Padmant et al., 1992). The result of the study agree with those of Sattar et al. (2013) and Bengtsson (1988) that Brassica species differed by $9 \%$ is their protein content. Analogous to maintenance of total soluble protein, the cultivars also responded deferentially in the maintenance of total free amino acids in the seed tissues. The cv. 'Faisal Canola' was the highest while the lowest in the cv. 'Bulbul-98' in total free amino acid. The results corroborate with those of various investigators (Das, 1998; Gentent et al., 1996; Muhammad et al., 2007) that protein content is mainly attributed to the ability of different canola varieties utilizing natural nitrogen resources and its translocation to different plant parts in the in soil-water-plant continuum. The result of the study pertaining to maintenance of various cultivars of canola are similar to those of Sattar et al. (2013) and Bengtsson (1988).

The various cultivars differed significantly in attaining the shoot length. The maximum and minimum shoot length was recorded in cvs. 'DGL' and 'Faisal Canola', respectively. These significant differences among canola cultivars in shoot length might be due to differences in genetic background and geneticxenvironment interaction effects (El-Nakhlawy and Bakhashwain, 2009; Mirzai et al., 2013). Some cultivars may be sensitive to eco-edaphic factors, while others may be tolerant (Sana et al., 2003).Various investigators (Maestro, 1995; Reddy and Reddy, 1998 also reported that different Brassica varieties differed substantially amongst themselves in attaining shoot length Sana et al. (2003) and Chaudhery et al. (1987) opined that variation in shoot length in different varieties is mainly attributed to their genetic potential under the specific ecological conditions. The existence of variation in maintaining differential chlorophyll content by various cultivars of canola signified the potential absolute differences in the performance of photosynthetic process. These variation in maintenance of chlorophyll content might be due to specific chlorophyll synthesizing enzymes, such as chlorophllase and peroxidase (Majumadar et al., 1991).These results agree with those of (Taiz and Zeiger, 2006; Din et al., 2011) that there were significant differences among various canola varieties for leaf chlorophyll $a$ and $b$ content.

The productivity of canola crop is a cumulative effect of different components of yield, i-e., number of branches plant ${ }^{-1}$, number of pods plant ${ }^{-1}, 100$ seed-weight and total seed weight plant $t^{-1}$. Among these determinants, the number of pods ${ }^{-1}$ is a major contributing component in determining the productivity level of canola crop under certain production ecologies. The maximum and minimum number of pods plant ${ }^{-1}$ was observed in cvs. 'Cyclone' and 'Shiralee', respectively. Khan et al. (2006b) also reported significant differences in number of pods per plant in Brassica species. In an earlier study, Chaudhary et al. (1987) also found positive and significant correlation between number of pods plant ${ }^{-1}$ and produce of seed yield in different varieties of mustard crop. These results agree with those of other investigators (Sattar et al., 2013; Cheema et al., 2001a, 2012;
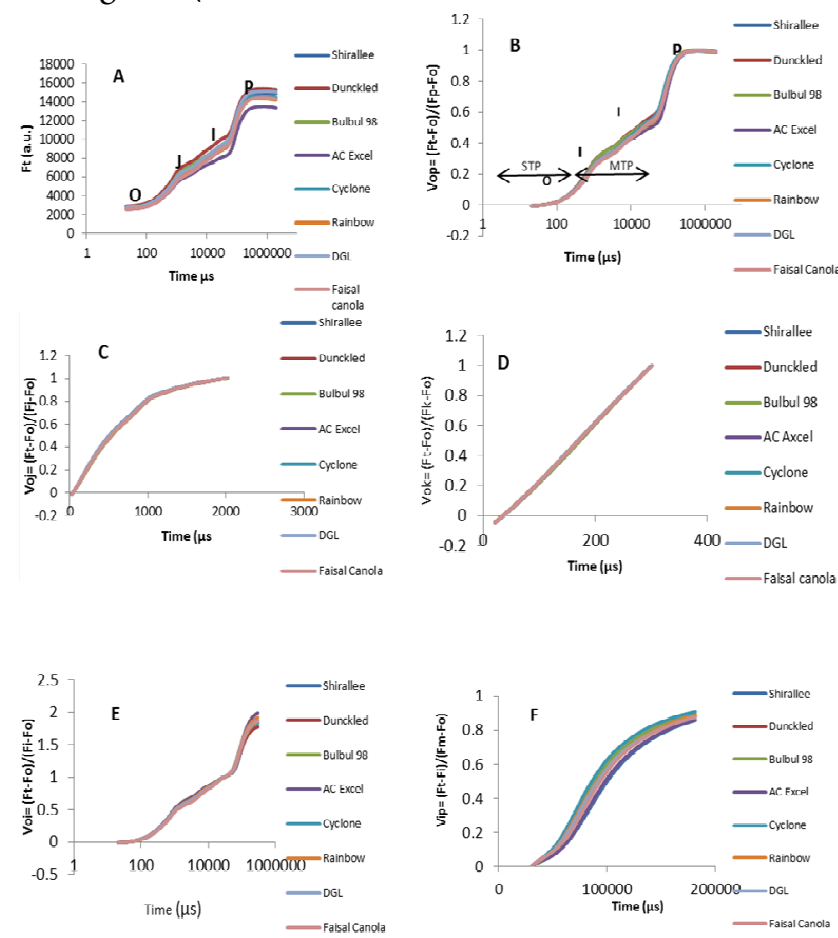

Fig. 2. (A) Chl. a florescence transients double normalized between two florescence extremes $F_{O}$ and $F_{K}$ phases $V_{O k}=(F t$ - $\mathrm{Fo}) /\left(\mathrm{F}_{\mathrm{K}}\right.$ - $\left.\mathrm{Fo}\right)$; (B) Chl. a florescence transients double normalized between two florescence extremes $F_{O}$ and $F_{K}$ phases $\mathrm{V}_{\mathrm{OI}}=(\mathrm{Ft}-\mathrm{Fo}) /\left(\mathrm{F}_{\mathrm{I}}-\mathrm{Fo}\right) ;$ (C) Chl. a florescence transients double normalized between two florescence extremes $F_{I}$ and $F_{P}$ phases $V_{I P}=\left(F t-F_{I}\right) /\left(F_{P}-F_{I}\right)$; (D) Kinetic difference of $\mathrm{V}_{\mathrm{OP}}$ showing OP- bands obtained as line standard line; (E) Kinetic difference of $\mathrm{V}_{\mathrm{OJ}}$ showing $\mathrm{K}$ - bands obtained as line - standard line; $(\mathrm{F})$ Kinetic difference of $\mathrm{V}_{\mathrm{OK}}$ showing L- bands obtained as line - standard line. 


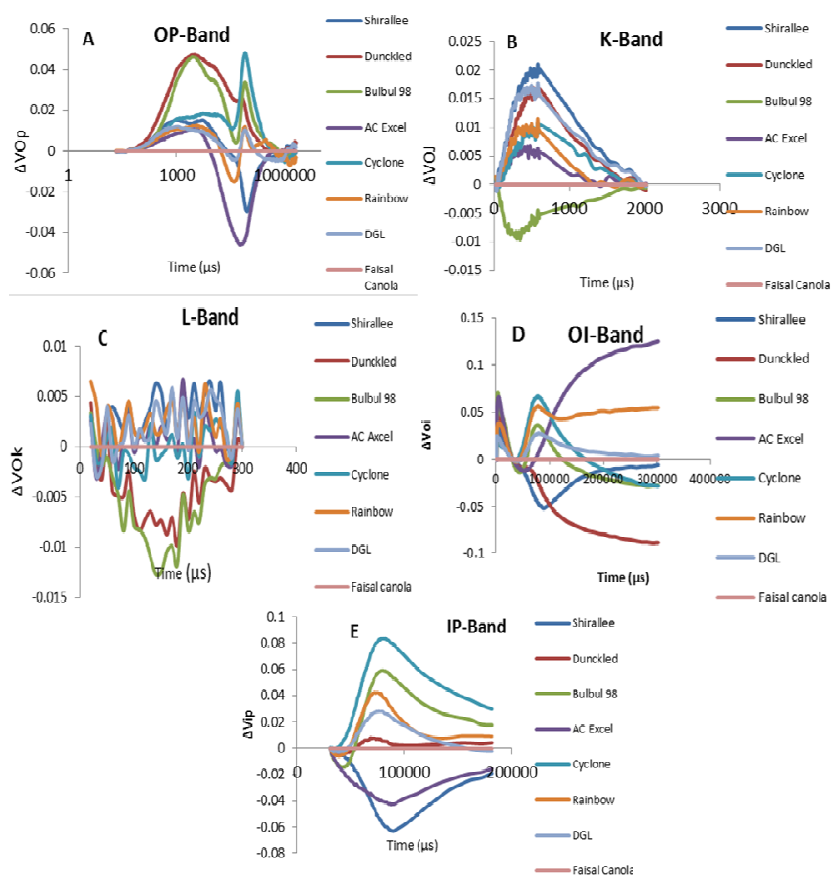

Fig. 3. (A) Kinetic difference of VOP; (B) Kinetic difference of VOJ; (C) Kinetic difference of VOK showing L - bands obtained as Lines - standard Lines; (D) Kinetic difference of VOI (E) Kinetic difference of VIP

Yasari and Patwardhan, 2006, Ec-Kholy et al., 2007) who found differences in production of variable number of pods plant ${ }^{-1}$ and attributed this variability to due to genetic make-up and interaction with environment under the production environments. The production of seed yield of canola is greatly contributed by quantum of 100 -seed weight. Maximum and minimum 100 seed weight was recorded in cvs. 'Rainbow' and 'Faisal Canola', respectively. The results of this study are in consonance with different researchers, Sattar et al. (2013), Cheema et al. (2001b, 2012) and Sana et al. (2003), who found substantial variation in maintenance of 100 seed weight by various cultivars of Brassica species. These results are also in harmony with Kjellström (1993), Mekki (2003) and Khoshanazar et al. (2000) who found differences in seed yield among different cultivars. The various yield forming processes resulted in the production of total seed weight per plant. Maximum and minimum total seed weight was recorded in cvs. 'Rainbow' and 'Dunkled', respectively. The result of our study are correlated with those of Mekki (2003), El-Kholly (2007) and Sattar et al. (2013), that seed is cumulative interaction of various components of yield processes.

The various cultivars of canola assimilated and translocated differential concentration of $\mathrm{K}^{+}$and $\mathrm{Na}^{+}$nutrients in their shoot and root organs. Maximum quantities of $\mathrm{K}^{+}$nutrient were absorbed by leaf tissues of cvs. 'Dunkled' and 'DGL', respectively. Moreover, cultivars 'Dunkled' and 'Ac-Excel' absorbed maximum quantity of $\mathrm{Na}^{+}$nutrient in their leaf and root tissues, respectively. The existence of variation in absorption pattern of nutrients is attributed to inherent capacity of various Brassica species to absorb and ability to retain to by different organs. These results are in harmony with those of Shirazi $e t$ al. (2011); Yasir et al. (2008) that pattern of distribution of nutrients is quite different due to genetic makeup of crop. Plants and interactive effective impacted by external regards of biotic and abiotic stresses. These results are also in agreement with those of Jan $e t$ al. (2002), Marschner (2011) and Ceccoti (1996).

The chlorophyll ' $a$ ' fluorescence technique revealed alterations in Photosystem II bioenergetics and simultaneously reflecting photosynthetic processes (Fig. 3). The changes in $\mathrm{F}_{\mathrm{o}}$ values were attributed to different genetic potential. The O-I part denoted the kinetics proportion for reduction/oxidation of the plastoquinone (PQ) pool (Guha et al., 2013), whereas, the I-P phase revealed changes in the electron flux from reduced plastoquinone (plastoquinol $\mathrm{PQ} \mathrm{H}_{2}$ ) to the final electron acceptor of PSII (Guha et al., 2013). The appearance of attenuated peaks in the I-P phase of OJIP transients was apparently caused by PSI associated limitations (Guha et al., 2013; Munday et al., 1969; Van Heerden et al., 2007). The structural integrity and stability of PSII were largely maintained as reflected by the $\mathrm{L}$ and $\mathrm{K}$ bands (Fig. 3 ) and $\Delta$ voj, $\Delta$ voi and $\Delta$ vjp plots (Guha et al., 2013). Rc/ABC (density of reaction center) was increased in cv. 'Bulbul-98' and decreased in cv. 'ACExcel'. Data showed that maximum photosynthesis occurred in cv. 'Bulbul-98' and minimum in cv. 'AC-Excel'. According to values of performance index, cv. 'Faisal Canola' showed maximum values, while density of reaction center was greater in cv. 'Bulbul-98' and this cv. had also indicated maximum biomass production.

\section{Conclusion}

The present study demonstrated the existence of a wide variation in biological yield, protein content, assimilation of nutrients and components of seed yield in various cultivars of canola crop Maximum seed yield was harvested from cv. 'Rainbow'. The higher photosynthetic (PSII) activity and greater portioning ability of photo-assimilates was determined in $\mathrm{cv}$. Rainbow. The various chlorophyll florescence parameters, quantum yield of photosystem II and electron transport performance index could be used as selection criteria for breeding of highly efficient canola cultivars.

\section{References}

Ahmad H, Islam M, Khan IA, Ali N, Rahman H, Inamullah (2008). Evaluation of advanced rapeseed line HS-98 for yield attributes and biochemical characters. Pakistan Journal of Botany 40:1099-1101.

Ali HG, Nadaf SK, Alkhamisi SA, AL-Bakri AN (2011). Adaptability of canola (Brassica juncea) varieties in different regions of Oman. International Journal of Agriculture Biology 13:831-834.

Aminpanah H (2013). Effect of nitrogen rate on seed yield protein and oil content of two canola (Brassica napus L.) cultivars. Acta Agricultura Slovenica 101:183-190.

Banga RS, Bisht S, Yadav A (2007). Proceedings of the $12^{\text {th }}$ International Rapeseed Congress, 26-30 March, Sustainable Development in Cruciferous Oilseed CropsProduction. Wuhan, China 3:246-247.

Bañuelos GS, Bryla DR, Cook CG (2002). Vegetative production of kenaf and canola under irrigation in central California. Industrial Crops and Products 15(3):237-245.

Bengtsson A (1988). Current winter rape cultivars. Svensk Frotidning 57(6):115-117.

Bradford MM (1976). A rapid and sensitive method for the quantification 
278

of microgram quantities of protien utilizing the principle of protein-dye binding. Analytical Biochemy 72:248-254.

CantagalloJE, Chimenti CA, Hall AJ (1997).Number of seeds per unit area in correlates with a photothermal quotient. Crop Science 37:17801786.

Ceccoti SP (1996). Plant nutrient sulphur: a review of nutrient balance, environment impact and fertilizers. Fertilizers Research 43:117- 125.

Chaudhary BD, Thukral SK, Singh DP, Singh P, Kumar A (1987). Combining abilities and components of variation in Brassica campestris. Research and Development Reporter 4(2):125-129.

Cheema MA, Malik MA, Basra SMA (2001a). Comparative growth and yield performance of different brassica varieties. International Journal of Agricultural Biology 3:135-137.

Cheema MA, Malik MA, Hussain A, Shah SH, Basra SMA (2001b). Effects of time and rate of nitrogen and phosphorus application on the growth, seed and oil yields of canola (Brassica napus L). Journal of Agronomy Crop Science 186:103-110.

Cheema MA, Saleem MF, Muhammad N, Wahid MA, Baber BH (2010). Impact of rate and timing of nitrogen application on yield and quality of canola (Brassica napus L.). Pakistan Journal of Botany 42:1723-1731.

Cheema MA, Sattar A, Wahid MA, Saleem MF, Sadiq S (2012). Growth, yield and quality response of various canola cultivars under agroecological condition of Faisalabad. Pakistan Journal of Agricultural Science 49:35-39.

Das TK (1998). Studies on the performance of some new mustard phenotypes under irrigated condition. Journal of Oilseeds Research 15:310-314.

Daun JK (2007). Quality of canola (Brassica napus L.) varieties in Western Canada: Evaluation of variability due to genetic, year and environmental conditions using data from Canadian Grain Commission Harvest Surveys and from Environment Canada Meteorological stations. Canola Council of Canada, Winnipeg. In: Fu T, Guan C (Eds). Proceedings of the $12^{\text {th }}$ International Rapeseed Congress. Sustainable Development in Cruciferous Oilseed Crops Production, Vol. V. Quality,Nutrition, Processingand Trade pp 10-14.

Diepenbrock W (2000). Yield analysis of winter oilseed rape (Brassica napus L.) a review. Field Crops Research 67:35 49 .

Din J, Khan SU, Ali I, Gurmani AR (2011). Physiological and agronomic response of canola varieties to drought stress. The Journal of Animal and PlantSciences 21:78-28.

Economic Survey of Pakistan (2015). Economic Survey of Pakistan 2014 2015. Ministry of Finance, Government of Pakistan, Islamabad, Pakistan.

El Habbasha ESF, El Salam MA (2009, May). Response of two canola varieties (Brassica napus $\mathrm{L}$.) to nitrogen fertilizer levels and zinc foliar application. Proceedings of the International Plant Nutrition Colloquium XVI. UC Davis, Department of Plant Sciences. Retrieved from:http://eprints.cdlib.org/uc/item/68f0h22d.

El-Nakhlawy FS, Bakhshwain AA (2009). Performance of canola (Brassica napus $\mathrm{L}$.) seed yield, yield components and seed quality under the effects of four genotype and nitrogen fertilizer rates. Meteorology, Environment and Arid Land Agriculture Sciences Journal 20:33-47.

Fayyaz-ul-Hassan, Manaf M, Qadir G, Basra SMA (2007). Effects of sulphur on seed yield, oil protein and glucosinolates of canola cultivars. International Journal of Agriculture and Biology 9:504508.

Gentent A, Majumdar MNA (1998). Drought stress effects on seed yield of Ethiopian mustard in Saskatchewan. Canadian Journal of Plant Sciences 76:387-392.

Goodwin MA (2004). A review of the impact of environment and agronomic practices on quality of Canadian canola oil. Canola Council ofCanada, Winnipeg.

Government of Pakistan (2014). Agricultural Statistics of Pakistan, 20132014. Ministry of National Food Security and Research. Islamabad, Pakistan.

Guha A, Sengupta D, Reddy AR (2013). Polyphasic chlorophyll a fluorescence kinetics and leaf protein analyses to track dynamics of photosynthetic performance in mulberry during progressive drought. Journal of Photochemistry and Photobiology B: Biology 119:71-83.

Hamilton PB, Van Slyke DD(1943). Amino acid determination with Ninhydrin Journal of Biology and Chemistry 150:231-233.

Jan A, Khan N, Khan IA, Khattak B (2002). Chemical corporation of canola as affected by nitrogen and sulphur. Asian Journal of Plant Sciences 1:519-521.

Khan FA, Ali S, Shakeel A, Saeed A, Abbas G (2006a). Correlation analysis of some quantitative characters in Brassica napus L. Journal of Agricultural Research 44:7-14.

Khan FA, Ali S, Shakeel A, Saeed A, Abbas G (2006b). Genetic variability and genetic advance analysis canola (Brassica napus L.) cultivars affected by planting date and water deficit stress. African Journal of Biotechnology 10:9309-9313.

Khehra MK, Singh P (1998). Sensitivity and performance of some Brassica napus genotypes in stress and non-stress environments. Crop Improvement Industrial 15:209-211.

Khoshanazar PR, Ahmadi MR, Ghannda MR (2000). A study of adaptation and yield capacity of rapeseed (Brassica napus L.) cultivars and lines. Indian Journal of Agriculture Science. 31:341-352.

Kjellström C (1993). Comparative growth analysis of Brassica napus and Brassica juncea under Swedish conditions. Canadian Journal of Plant Science 73(3):795-801.

Kolte SJ, Awasthi RP, Vishwanath R (2000). Divya mustard: a useful source to create Alternaria black spot tolerant dwarf varieties of oilseed brassicas. Journal Plant Varieties and Seeds 13(2):107-111.

Kumar A, Singh DP, Singh P (1994). Influence of water stress on photosyntehsis, transpiration, water-use efficiency and yield of Brassica napus L. Field Crops Research 37:95-101.

Mailer R (2009). Grain quality. In: McCaffery D, Potter T, Marcroft S, Pritchard F (Eds). Canola best practice management guide for southeastern Australia. Grains Research and Development Corporation, NewSouth Wales, Australiapp 7-10.

Marschner H (2011) Marschner's mineral nutrition of higher plants. Academic Press.

Mastro G (1995). Rape, Metapontum area. Informatore Agrario 51:26-27.

Mekki BB (2003).Proceedings of the $11^{\text {dh }}$ International Rapeseed Congress, 6-10 July, 2003. The Royal Veterinary and Agriculture University, Copenhagen Denmark 3:915-917. 
Mirzaei A, Naseiri R, Moghadam A, Esmailpour-Jahromi M (2013). The effects of drought stress on seed yield and some agronomic traits of canola cultivars at different growth stages. Bulletin Environmental Pharmacology Life Science 2:115-121.

Muhammad N, Cheema MA, Wahid MA, AhmadN,Zaman M (2007). Effects of source and method of nitrogen fertilizer application on seed yield and quality of canola (Brassica napus L.) Pakistan Journal of Agricultural Science 44:7478.

Majumdar S, Ghosh S, Glick BR, Dumbroff EB (1991). Activities of chlorophyllase, phosphoenolpyruvate carboxylase and ribulose-1, 5-bisphosphate carboxylase in the primary leaves of soybean during senescence and drought. Physiologia Plantarum 81(4):473-480.

Mukhtar E, Siddiqi E H, Bhatti KH, Nawaz K, Hussain K (2013).Gas exchange attributes can be valuable selection criteria for salinity tolerance in canola cultivars (Brassica napus L.). Pakistan Journal of Botany 45:3540.

Munday JC, Govindjee JR (1969). Light induces change in the in the fluorescence yield of chlorophyll a in vivo. 3. The dip and the peak in the fluorescence transients of Chlorella pyrenoidosa. Biophysical Journal 9:121.

Padmani DR, Porwal BC, Jain PM, Patel J, Patel JC (1992). Effect of irrigation and nitrogen on yield and yield attributes of mustard (Brassica juncea L.). Indian Journal of Agronomy 37:477-480.

Paramjit S, Khehra MK, Gupta VP (1991). Variability and correlation studies for oil and seed yield in gobhi sarson. Crop Improvement 18(2):99-102.

Parveen K, Singh RP, Singh RC, Subhash C (1996). Influence of irrigation scheduling on growth and seed quality of mustard. Annals Agriculture Research 17:114-116.

Rathke GW, Behrens T, Diepenbrock W (2006). Integrated nitrogen management strategies to improve seed yield, oil content and nitrogen efficiency of winter oilseed rape (Brassica napus L.): A review. Agriculture Ecosystem Environment 117:80-108.

Reddy CS, Reddy PR (1998). Performance of mustard varieties on alfisols of Rayalaseema Region of Andhara Pradesh. Journal of Oilseeds Research 15:379-380.

Reyan J, Estefan G, Rashid A (2001). Soil Analysis Laboratory Manual. $2^{\text {nd }}$ ed. International Center for Agricultural Research on Dry Areas (ICARDA), Syria, 172p.

Sahrawat KL, WaniSP,SubaraoA, PardhasaradhiG(2011).Management of emerging multi-nutrient deficiencies: a prerequisite for sustainable enhancement of rainfed agricultural productivity. In Wani SP, Rockstorm J, Sahrawat KL (Eds). Integrated Watershed Management in Rainfed Agriculture. CRC Press/Balkema, 2300 AK Leiden, The Netherlandspp 281-313.

Sana M, Ali A, Asghar M, Saleem MF, Rafeeq M (2003). Comparative yield potential and oil contents of different canola cultivars (Brassica napus L.). Pakistan Journal of Agronomy 2:1-7.
Sattar A, Cheema MA, Wahid MA, Saleem MF, Ghaffari MA, Hussain S, Arshad MS (2013). Effect of sowing time on seed yield and oil contents of canola varieties. Journal of Global Innovation in Agriculture and Social Science 1:1-4.

Shirazi MU, Rajput MT, Khan MA, Ali M, MujtabaS, Shereen A, Mumtaz S, Ali M (2011). Growth and ions $\left(\mathrm{Na}^{+}, \mathrm{K}^{+}\right.$and $\left.\mathrm{Cl}\right)$ accumulating pattern of some Brassica genotypes under saline-sodic field condition. Pakistan Journal of Botany 43:2661-2664.

Sidlauskas G, Bernotas S (2003). Some factors affecting seed yield of spring oilseed rape. Agronomy Research 1:229-243.

Snowdon RJ, Friedt W (2004). Molecular markers in Brassica oilseed breeding; current status and future possibilities. Plant Breeding 123:1-8.

Steel RGD, Torrie JH, Dickey DA (1997). Principles and Procedures of Statistics: A Biometrical Approach. 3rd ed New York, NY, USA: McGraw-Hill.

StrickerJA, Prine JA, Riddle TC (1997). Yield of kenafgrown on two soils at two locations in Florida. Soil Crop Science Society Florida Proceedings 56:35-37.

Stringam GR, Degenhardt DF, Thalgarajah MR, Bansal VK, Hawkins GP (2002). Kelsey summer rape. Canadian Journal of Plant Science 82:559-560.

Tahir M, Ali A, Nadeem MA, Tanveer A, Sabir QM (2007). Performance of canola (Brassica napus L.) under different irrigation levels. Pakistan Journal of Botany 39:739-746.

Taiz L, Zeiger E (2006). Plant physiology. 4th edition, Sinauer Associates, Sunderland.

Valizadeh N, Birshekari B (2011). Determination of economical yield loss threshold of chenopodium album at interference with rapeseed (Brassica napus L.).Journal of Food Agriculture Environment 9:409-412.

Van Heerden PDR, Swanepoel JW, Kruger GHJ (2007). Modulation of photosynthesis by drought in two desert scrub species exhibiting $\mathrm{C}_{3}$ mode $\mathrm{CO}_{2}$ assimilation. Environmental and Experimental Botany 61:124136.

Wahid MA, Cheema MA, Malik MA, Ashraf M (2009). Comparative performance of canola hybrids in response to different phosphate fertilizers. International Journal of Agriculture Biology 11:306-310.

Wiedenhoeft M, Bharton BA (1994). Management and environment effects on Brassica forage quality. Agronomy Journal 86:227-237.

Yasari E, Patwardhan AM, Ghole VS, Omid GC, Ahmad A (2008). Relationship of growth parameters and nutrient uptake with canola yield and yield contribution at different nutrients availability. Pakistan Journal of Biology Sciences 11:845-853.

Yasari E, Patwardhan AM (2006). Physiological analysis of the growth and development of canola (Brassica napus L.) Asian Journal of Plant Sciences 5:745-752.

Zhao Y, Wang MI (2004). Inheritance and agronomic performance of an apetalousflower mutant in Brassica napus L. Euphytica 137:381-386. 